This manuscript is contextually identical with the following published paper:

Bolgovics, Á; Ács, É; Várbíró, G; Görgényi, J; Kiss, KT; Földi, A; Nagy-László, Z; Trábert, Z; Borics, G (2017)Benthic diatom-based lake types in Hungary. FUNDAMENTAL AND APPLIED LIMNOLOGY 189: (2) pp. 105-116. (2017) DOI: https://doi.org/10.1127/fal/2016/0942

The original published PDF available in this website: http:/www.ingentaconnect.com/content/schweiz/fal/2017/00000189/00000002/art00003

\title{
Benthic Diatom-Based Lake Types in Hungary
}

\author{
Ágnes Bolgovics ${ }^{1,2}$, Éva Ács ${ }^{3}$, Gábor Várbíró ${ }^{1}$, Judit Görgényi ${ }^{1,2}$, Keve Tihamér Kiss ${ }^{3}$,
} Angéla Földi ${ }^{2}$, Zsolt Nagy-László ${ }^{4}$, Trábert Zsuzsa ${ }^{1}$, Gábor Borics ${ }^{1}$

\footnotetext{
${ }^{1}$ MTA Centre for Ecological Research, Danube Research Institute, Department of Tisza Research, H-4026 Debrecen, Bem square 18/c., Hungary

${ }^{2}$ University of Eötvös Loránd, H-1117 Budapest, Pázmány Péter Str. 1/A, Hungary

${ }^{3}$ MTA Centre for Ecological Research, Danube Research Institute, H-1113 Budapest, Karolina Str. 29, Hungary

${ }^{4}$ University of Pannonia, H-8200, Veszprém, Egyetem Str. 10, Hungary
}

\begin{abstract}
Hydromorphological and chemical properties of water bodies have pronounced influence on the occurrence and distribution of biological elements in the aquatic ecosystems. Based on a series of abiotic characteristics, seventeen lake types were established in Hungary for management purposes. Benthic diatom assemblages were studied in shallow standing water bodies in Hungary in order to provide a biological validation of these types. Species composition and abundance of the occurring taxa were analysed. By their diatom taxonomic composition five basic lake types could be distinguished; two calcareous lake types, which differ in size and in their trophic characteristics and three types within the group of high salinity lakes. In this latter group the astatic and perennial lakes showed considerable differences. These results have great practical importance, because biological validation of the hydromorphological lake typology is the first step for reliable assessment of the ecological status of water bodies.
\end{abstract}

\section{Introduction}

Aquatic ecosystems are the most threatened ecosystems world-wide (Revenga et al. 2000). For managing the preservation and restoration of aquatic ecosystems across Europe the European Commission implemented the Water Framework Directive (WFD, 2000/60/EC). The directive is considered to be the most ambitious and comprehensive document of European environmental legislation (Moss et al. 2003). WFD requires member states to 
monitor and assess the quality of surface waters in order to identify and reverse negative trends in the ecological state of water bodies. The WFD and the various supportive documents (Anonymous 2003) provide guidance to ensure its implementation in a consistent way across Europe; however, it is still a major challenge for the member states. Ecological state assessment of water bodies has to be based on the evaluation of the actual status in comparison to the type specific reference conditions (WFD, 2000/60/EC). Therefore, establishment of river and lake typologies is the first step in the assessment process. It has been known from the early decades of the last century that hydromorphological characteristics of lakes basically determine the composition of lake biota (Murray et al. 1910). Ecoregions, size, depth, altitude, hydrological regime and geology are considered as the most important variables influencing distribution and abundance of biological elements. By combining these variables, hundreds of lake types can be defined but forty-eight were proposed as "core types" (Moss et al. 2003). Besides these variables other biologically important type descriptor variables can also be applied in order to reach greater and clearer separation of the types. Type of the stratification, lake residence time, acid neutralizing capacity, water level fluctuation and several other properties were applied in the national typologies across Europe (Borics et al. 2014). The resulted types, so-called top-down types, have been created accordingly; while ecological similarities or dissimilarities of the types have not been considered. However, biological elements used in ecological state assessment are not sensitive to all the type descriptor variables and this makes possible the merging of the types, and thus, the simplification of the typologies (Zenker and Baier 2009). Phytobenthos is one of the biological elements that required by the WFD and included in ecological status assessments. Benthic diatoms, being a species-rich and ecologically diverse group of algae, are used increasingly in ecological monitoring as proxies for phytobenthos. Several diatom-based metrics have been developed (Coste in Cemagref 1982, Rott et al. 1997, 1999) and used for river quality assessment in European countries (Birk et al. 2012, Rimet et al. 2005, Van Dam et al. 2007, Várbíró et al. 2012) and usefulness of these metrics in lake quality assessment has been demonstrated (Ács et al. 2005, Bolla et al. 2010, Blanco 2004). A European scale comparison of the diatom-based national assessment methods has been done for three common European lake types (low, moderate and high alkalinity lakes) by Kelly et al. (2014). However the number of hydromorphological lake types within countries is much higher (Kolada et al. 2005, Borics et al. 2014), and only a few of them can be assigned to the common intercalibration types. 
Based on hydromorphological characteristics seventeen lake types were established in Hungary (Szilágyi et al. 2008). As a result of the phytoplankton-based validation of these types the numbers have been reduced to four (Borics et al. 2014). However in that study the authors noted that there was no clear overlap between the biomass-based types and the types based on phytoplankton composition. The four types were distinguished by their trophic characteristics but in several types eutrophication may not be the key pressure (Hering et al. 2010). Large steppe lakes (Borics et al. 2014) and shallow, turbid soda lakes are characteristic elements of the landscape in the Carpathian Basin (Felföldi et al. 2009). The common feature of these lakes is that they are naturally eutrophic, or hypertrophic (Boros et al. 2006, StengerKovács et al. 2014), but other characteristics such as pH, conductivity, and macrophyte composition show significant differences. However, it is still a question whether these differences appear in the composition of the benthic microflora. Diatom based methods are promising tools in lake quality assessment, but simplification of the top-down typologies and establishment of diatom-based lake types are required. Therefore, the aim of the study is to present a diatom-based bottom-up typology and simplification of the hydromorphology based top-down typology for the lakes in the Carpathian basin.

\section{Materials end Methods}

\section{Database}

Benthic diatom data derived from the Hungarian National Water quality monitoring survey and from the database of the Danube Research Institute. To avoid mis-grouping, only data for the least disturbed sites were considered during the analyses.

For selecting the least disturbed sites we applied type-dependent screening criteria. In case of those lakes where there is only one lake within one lake type (Lake Balaton, Lake Velencei and Fertö) we used data from last decade, because great improvement in lake quality could be observed in this period (Istvánovics and Somlyódy 2001; Ács et al. 2005).

The following criteria were applied to the other lake groups: no point source pollution, no intensive stocking of fish, no artificial modification of the shoreline, complete zonation of macrophytes. Since very shallow high alkalinity soda lakes are considered naturally hypertrophic (Boros et al. 2014) exclusion criteria for nutrients have not been applied in this lake group. Although high alkalinity calcareous lakes can also be considered naturally eutrophic (Borics et al. 2014), extreme values of nutrients unanimously refer to anthropogenic 
load. Therefore, for the lakes in this lake group the following screening criteria were applied: $\mathrm{P}<250 \mu \mathrm{g} \mathrm{I}^{-1}$ and $\mathrm{N}<2000 \mu \mathrm{g} \mathrm{l}^{-1}$ (lake mean values).

Land use is considered important screening criterion across Europe (Pardo et al. 2012; Kelly et al. 2014), but this criterion has not been applied in this study, because previously it was demonstrated that differences in land use appear not to be relevant for lake quality at this region, because the importance of land use is exceeded by that of lake use, i.e., intensity of fishing and fish stocking (Borics et al. 2013).

\section{Sampling}

Altogether six hundred thirty-nine samples were collected from one hundred forty-four sampling sites belonging to seventy-five water bodies in the middle of the vegetation period (from May to September) between 2010 and 2016. Benthic diatom samples were collected from five reed stalks per sampling site from the well illuminated littoral zones of lakes. Diatom samples were preserved with Lugol's solution and were stored in plastic containers until processing.

\section{Sample processing}

The frustules were cleaned with hydrochloric acid and hydrogen peroxide, subsequently washed in distilled water and mounted with Naphrax ${ }^{\circledR}$ mounting medium (MSZ EN 13946:2014). Identification was performed according to Krammer \& Lange-Bertalot (19861991), Krammer (2003) and Hofmann et al. (2011).

\section{Approaches of biological validation of the hydromorphological lake types}

There are two options for establishing lake types in which both hydromorphological and biological characteristics of waters are considered (Fig. 1).

Option 1: during the implementation of the WFD one of the first steps is the establishment of a water body typology. The typology proposed by the WFD has to be based on the broad scale ecoregions, hydromorphological, physical and chemical characteristics of water bodies, and thus, it can be considered as a top-down typology (Zenker and Baier 2009). This typology can be simplified if biological characteristics of the hydromorphological types are compared directly and types with no significant differences are merged. The disadvantage of this approach is that biological homogeneity of the hydromorphological types is supposed a priori (Mykrä et al. 2009), thus splitting off the hydromorphological types is not possible. 
Option 2: when this option is applied the top-down typology is ignored because comparison of the biological characteristics of lakes is done at lake (or site) level. During this process, the whole lake population is separated into smaller groups in which lakes sharing similar biological characteristics are pooled. This can be accomplished with a step by step process (clustering), or with ordination techniques. This approach results in a so-called bottom-up typology. These biological types have to be accommodated to the hydromorphological types. Splitting of the hydromorphological types is feasible as long as it is corroborated by biological evidences. During this study both options were combined.

\section{Statistical analyses}

Statistical analysis was based on species abundance data. Non-metric multidimensional scaling (NMDS), using Bray-Curtis similarities, was applied for grouping of the hydromorphological lake types (Option 1). In the second step this technique was applied to data from entire lakes (Option 2). Statistical differences between the groups obtained by the NMDS were tested by PERMANOVA (Anderson et al. 2008). Analysis was performed on site level. The proposed biologically validated lake types were characterised by the diatom species using Similarity percentage analysis (SIMPER; Clark 1993). SIMPER is a multivariate, exploratory method that assesses the contribution of each taxon to the BrayCurtis dissimilarities between contrasted groups. Statistical analysis was performed using PAST package (Hammer et al. 2001).

Species diversity was calculated by the Shannon formula (1948). The trophic state of the proposed types was characterised by the trophic metric of the OMNIDIA software (Lecointe et al. 1993) using the range zero to twenty. The highest values indicate lower trophic conditions. The significance of the differences in diversity and TID values were tested by the Kruskal-Wallis test. Analysis was done on a sample level.

\section{Results}

\section{Establishment of the biologically validated lake types}

Ordination of the hydromorphological lake types resulted in two distinct groups (Fig. 2). The group of high salinity lakes (with $\mathrm{Na}^{+}$and $\mathrm{Mg}^{2+}$ dominance) and the moderate salinity $\left(\mathrm{Ca}^{2+}\right.$ dominated) lakes clearly separated from each other according to diatom composition (Permanova of Bray-Curtis similarity $\mathrm{p}<0.05$ ). Further separation of the two subgroups was based on site level data (Option 2). The NMDS ordination of the site level data displays two 
groups in the moderate (Fig. 3) ( $<<0.05)$, and three groups in the high salinity lakes (Fig. 4). Diatom assemblages of Lake Balaton differed significantly from that of the other $\mathrm{Ca}^{2+}$ dominated lakes (Fig. 3). Within the groups of high salinity lakes the following three groups could be distinguished: 1. large steppe lakes (Lake Velencei and Lake Fertö), 2. $\mathrm{Na}^{+}$ dominated perennial saline lakes, and $3 . \mathrm{Na}^{+}$dominated astatic saline lakes (PERMANOVA p $<0.05$ ) (Fig. 4). The proposed five bottom-up types could be accommodated to the hydromorphological lake types (Table 1 and 2). Species characteristics for the given lake types (identified by SIMPER analysis) are shown in Tables 3, 4 and 5. (Physical and chemical characteristics of the proposed lake types are shown in Table 6.)

\section{Characterisation of the lake types}

Significant differences were found in the Shannon diversity values between the astatic [4] and perennial [5] high salinity lakes (Fig. 5). The highest values were observed in the case of the perennial lakes, while the lowest ones in the group of astatic lakes. Diversity of the large steppe lakes Fertő and Lake Velencei ( $3^{\text {rd }}$ biological type) did not show differences from the others, and the values fell in the middle range of diversity (Fig. 5). In the two groups of calcareous lakes (Balaton [1] and others [2]) differences in diversity could also be demonstrated $(\mathrm{p}<0.05)$ (data not shown).

The low values of the trophic metrics indicate that lakes in the Carpathian basin are eutrophic or hypertrophic. Differences in the distribution of the trophic metric scores have also been shown both for the moderate and high salinity lakes (Fig. 6). In the group of moderate salinity calcareous lakes, metric scores calculated for Lake Balaton [1] samples were significantly higher than those characterised in the other [2] calcareous lakes.

Significant differences were also found in the trophic metric scores among the three proposed groups of high salinity lakes (Fig. 6). The lowest values were characteristic for the astatic saline lakes [4], while the highest scores were obtained for the large steppe lakes (Fertő and Lake Velencei [3]). Trophic scores of the perennial high salinity lakes [5] appeared to be between the values of the two above mentioned types.

\section{Discussion}

Establishment of the biologically validated lake types

NMDS ordination of the species abundance data resulted in a clear and consistent distinction between the highly saline sodium and magnesium dominated lakes and moderate salinity calcareous ones. This result is consistent with that obtained in a recent study which was based 
on the analysis of phytoplankton (Borics et al. 2014). Diatom flora of high salinity lakes consists of species with wide ecological valence that enables their survival in extreme environmental conditions (Hecky \& Kilham 1973). In the highly saline lakes of the Carpathian Basin species are subject to various types of extremities, such as high salt content and high organic and inorganic load (Stenger-Kovács et al. 2014, Boros et al. 2006). However, we note that from the present analysis separation of these extremities cannot be made.

Separation of the two types of the moderate salinity calcareous lakes (Balaton and others) can be explained partly by the trophic differences and partly by the unique microflora of the Balaton (Bolla et al. 2010).

In the literature on saline lakes several halophilic species are mentioned such as Nitzschia frustulum, Rophalodia brebissonii, Halamphora veneta (Hecky \& Kilham 1973, Silva et al. 2010, Stenger-Kovács et al. 2014) and these taxa were also characteristic in the studied high salinity lakes. However microflora of the lakes belonging to the highly saline lake group appeared to be similar but the abundance of these taxa was remarkably different in the three lake types (Table 5). These differences in abundance values are responsible for the separation of the lake groups rather than unique species that might occasionally occur in one of the lake groups.

\section{Characterisation of the lake types}

Although earlier it was believed that diversity of algae in eutrophic lakes is usually lower than that of oligotrophic ones (Moss 1973), experimental studies proved that diversity is influenced by the fluctuation of resources rather than the quantity of them (Sommer 1984). Both experimental (Carrick et al. 1988) and field studies (Leira et al. 2009) demonstrated that nutrient enrichment narrows the niche of some sensitive benthic diatom taxa, but simultaneously creates favourable conditions for many specialised species. However, low diversity values might be related to natural processes such as grazing or other disturbances (DeNicola and Kelly, 2014). This means that higher nutrient concentration does not necessarily coincide with decreasing species diversity. Therefore, the higher diversity observed in the case of Lake Balaton, as compared to other calcareous lakes, cannot be explained by its lower nutrient content. Results on the species/area relationship for algae revealed the importance of lake size as a control of diversity (Bolgovics et al. 2016, Borics et al. 2016), therefore the size differences between Lake Balaton and the other considerably smaller lakes may be responsible for the observed differences of diversity. 

$=0$

The astatic/perennial distinction which was observed for Shannon diversity within the group of saline lakes has also been demonstrated for the phytoplankton (Borics et al. 2014), which indicates that desiccation puts a stress on both planktonic and benthic algae and thus coincides with a decrease in diversity (Borics et al. 2013). In the group of high salinity lakes significant differences in diversity were attributable to the very low values found in the astatic lake group. In this group the biota is exposed to double stress i.e., desiccation of the lake basin, and the extremely large salt content. Both phenomena exert strong selective pressure on the species pool of the lakes, and results in very low Shannon diversity and species richness values in pristine soda pans (Stenger-Kovács et al. 2016).

Desiccation means that for a considerable period of time the lake bed becomes a terrestrial habitat where algae are subjected to heat and osmotic stress (Souffreau et al. 2010), and only those taxa can survive which have special adaptations (i.e., migration, production of extracellular polysaccharids) (McKew et al. 2011). Even in those periods when water is present in the lake basin diatoms are under strong selection to adapt to pressures that the high salinity and the dominance of sodium exert on them (Hecky \& Kilham 1973).

The results of the characterisation of the nutrient status of lakes by trophic scores is in accordance with that of a previous study (Borics et al. 2014) which suggest, that lakes in the Carpathian Basin are in the mesotrophic - hypertrophic range. An elevated trophic state is especially common in this group of saline lakes, because these lakes are endorheic (without outlet). Their water cannot leave the lake basin and are continuously enriched with nutrients mostly because of the birds which use the lakes for feeding and roosting (Boros et al. 2006).

\section{Conclusions}

The remarkable floristic and compositional differences in the benthic diatom flora of the studied shallow lakes in Hungary enabled the separation of five bottom-up lake types. These types could be clearly assigned to hydromorphological types, and this resulted in a rational simplification of the hydromorphological typology. These results are in accordance with those of previous studies which were based on the analysis of phytoplankton (Borics et al. 2014) and of aquatic macrophytes (Lukács et al. 2015). 西 
272 This study was funded by the National Research, Development and Innovation Office 273 (GINOP 2.3.3-15-2016-00019). 


\section{References}

Ács, É., Reskóné, N.M., Szabó, K., Taba, G. \& Kiss, K.T., 2005: Application of benthic diatoms in water quality monitoring of Lake Velence - recommendations and assignments. Acta Botanica Hungarica 47: 211-223.

Anderson, M.J., Gorley, R.N. \& Clarke, K.R., 2008: PERMANOVA + for PRIMER: guide to software and statistical methods. PRIMER-E, Plymouth, UK.

Anonymous, 2003: Common implementation strategy for the Water Framework Directive (2000/60/EC). Guidance document No. 10: river and lakes-typology, reference conditions and classification systems. European Commission, Luxembourg.

Birk, S., Bonne, W., Borja, A., Brucet, S., Courrat, A., Poikane, S., Solimini, A., van de Bund, W., Zampoukas, N. \& Hering, D., 2012: Three hundred ways to assess Europe's surface waters: an almost complete overview of biological methods to implement the Water Framework Directive. Ecological Indicators 18: 31-41.

Blanco, S., Cejudo-Figueiras, C., Tudesque, L., Bécares, E., Hoffmann, L. \& Ector, L., 2012: Are diatom diversity indices reliable monitoring metrics? Hydrobiologia 695: 199-206.

Bolla, B., Borics, G., Kiss, K. T., Reskóné, N.M., Várbíró, G. \& Ács, É., 2010: Recommendations for ecological status assessment of Lake Balaton (largest shallow lake of Central Europe), based on benthic diatom communities. Vie et. Milieu 60:197208.

Bolgovics, Á., Ács, É., Várbíró, G., Görgényi, J. \& Borics, G., 2016: Species area relationship (SAR) for benthic diatoms: a study on aquatic islands. Hydrobiologia 764: 91-102.

Borics, G., Tóthmérész, B., Várbíró, G., Grigorszky, I., Czébely, A. \& Görgényi, J., 2016: Functional phytoplankton distribution in hypertrophic systems across water body size. Hydrobiologia 764: 81-90.

Borics, G., Várbíró, G. \& Padisák, J., 2013: Disturbance and stress - different meanings in ecological dynamics? Hydrobiologia 711:1-7.

Borics, G., Lukács, B.A., Grigorszky, I., László-Nagy, Zs., G-Tóth, L., Bolgovics, Á., Szabó, S., Görgényi, J. \& Várbíró, G., 2014: Phytoplankton-based shallow lake types in the Carpathian basin: steps towards a bottom-up typology. Fundam. Appl. Limnol. 184: 23-34.

Borics, G., Nagy, L., Miron, S., Grigorszky, I., László-Nagy, Z., Lukács, B.A., László, G. and Várbíró, G., 2013: Which factors affect phytoplankton biomass in shallow eutrophic lakes? Hydrobiologia, 714:93-104. 
Boros, E., Bánfi, S. \& Forró, L., 2006: Anostracans and microcrustaceans as potential food sources of waterbirds on sodic pans of the Hungarian plain. Hydrobiologia 567: 341349.

Carrick, H.J., Lowe, R.L. and Rotenberry, J.T., 1988: Guilds of benthic algae along nutrient gradients: relationships to algal community diversity. Journal of the North American Benthological Society, 7: 117-128.

Clark, K.R., 1993: Non-parametric multivariate analyses of changes in community structure. Aust. J. Ecol. 18: 117-143.

Cemagref, 1982: Etude des méthodes biologiques d'appréciation quantitative de la qualité des eaux, Rapport Q.E. Lyon - Agence de l'Eau Rhône-Méditerranée-Corse, Lyon 218 p.

DeNicola, D.M. and Kelly, M., 2014: Role of periphyton in ecological assessment of lakes. Freshwater Science 33(2): 619-638.

Felföldi, T., Somogyi, B., Márialigeti, K. \& Vörös, L., 2009: Characterization of photoautotrophic picoplankton assemblages in turbid, alkaline lakes of the Carpathian Basin (Central Europe). Journal of Limnology 68: 385-395.

Hammer, Ø., Harper, D.A.T. and Ryan, P.D., 2001: PAST-PAlaeontological STatistics, ver. 1.89. Palaeontologia electronica, 4:1-9.

Hecky, R. E. \& Kilham, P., 1973: Diatoms in alkaline, saline lakes: ecology and geochemical implications. Limnol. Oceanogr. 18: 53-71.

Hering, D., Borja, A., Carstensen, J., Carvalho, L., Elliott, M., Feld, C.K., Heiskanen, A.S., Johnson, R.K., Moe, J., Pont, D. \& Solheim, A.L., 2010: The European Water Framework Directive at the age of 10: a critical review of the achievements with recommendations for the future. Science of the total Environment 408: 4007-4019.

Hofmann, G., Wermun, M. \& Lange-Bertalot, H., 2011: Diatomeen in Süßwasser-Benthos von Mitteleuropa. A.R.G. Gantner Verlag, Koeltz Scientific Books, Königstein.

Istvánovics, V. and Somlyódy L., 2001: Factors influencing lake recovery from eutrophication - the case of Basin 1 of Lake Balaton. Water Research, 35: 729-735.

Krammer, H. \& Lange-Bertalot, H., 1986-1991: Bacillariophyceae. -In: Ettl, H., Gartner, G., Gerloff, J., Heynig, H. \& Mollenhauer, D. (eds): Süßwasserflora von Mitteleuropa 2 (1-4). - Gustav Fischer, Stuttgart.

Kelly, M., Urbanic, G., Ács, É., Bennion, H., Bertrin, V., Burgess, A., Denys, L., Gottschalk, S., Kahlert, M., Karjalainen, S.M. \& Kennedy, B., 2014: Comparing aspirations: intercalibration of ecological status concepts across European lakes for littoral diatoms. Hydrobiologia 734: 125-141. 
Kolada, A., Soszka, H., Cydzik, D. \& Gołub, M., 2005: Abiotic typology of Polish lakes. Limnologica-Ecology and Management of Inland Waters 35: 145-150.

Krammer, K., 2003: Cymbopleura, Delicata, Navicymbula, Gomphocymbellopsis, Afrocymbella. - In: Lange-Berlot, H. (ed.): Diatoms of the European Inland Waters and Comparable Habitats. A. R. Gantner Verlag, Ruggell.

Lecointe, C., Coste, M. and Prygiel, J., 1993: “Omnidia”: software for taxonomy, calculation of diatom indices and inventories management. Hydrobiologia, 269:509-513.

Leira, M., Chen, G., Dalton, C., Irvine, K. and Taylor, D., 2009: Patterns in freshwater diatom taxonomic distinctness along an eutrophication gradient. Freshwater Biology, 5.

Lukács, B.A., Tóthmérész, B., Borics, G., Várbíró, G., Juhász, P., Kiss, B., Müller, Z., László, G. \& Erős, T., 2015: Macrophyte diversity of lakes in the Pannon Ecoregion (Hungary). Limnologica-Ecology and Management of Inland Waters 53: 74-83.

McKew, B. A., Taylor, J. D., McGenity, T. J. \& Underwood, G. J., 2011: Resistance and resilience of benthic biofilm communities from a temperate saltmarsh to desiccation and rewetting. The ISME journal 5: 30-41.

Mykrä, H., Aroviita, J., Hämäläinen, H., Karjalainen, S.M., Visuri, M., Riihimäki, J., Miettinen, J. and Vuori, K.M., 2009: Utility of a single a priori river typology for reference conditions of boreal macroinvertebrates and diatoms. Fundamental and Applied Limnology/Archiv für Hydrobiologie, 175:269-280.

Moss, B., 1973: Diversity in fresh-water phytoplankton. American Midland Naturalist 90: $341-355$.

Moss, B., Stephen, D., Alvarez, C., Becares, E., Bund, W.V.D., Collings, S. E., Donk, E.V., Eyto, E.D., Feldmann, T., Fernández-Aláez, C., Fernández-Aláez, M.,Franken, R.J.M., García-Criado F., Gross, E.M., Gyllström, M., Hansson, L.-A., Ircine, K., Jarvalt, A., Jensen, J.-P., Jeppensen, E., Kairesalo, T., Kornijów, R., Krause, T., Künnap, H., Laas, A., Lill, E., Lorens, B., Luup, H., Miracle, M.R., Nöges, P., Nöges, T., Nykanen, M., Ott, I., Peczula, W., Peeters, E.T.H.M., Phillips, G., Romo, S., Russel, V., Salujöe, J., Scheffer, M., Siewertsen, K., Smal, H., Tesch, C., Timm, H., Tuvikene, L., Tonno, I., Virro, T., Vicente, E. \&Wilson, D., 2003: The determination of ecological status in shallow lakes - a tested system (ECOFRAME) for implementation of the European Water Framework Directive. Aquatic Conservation: Marine and Freshwater Ecosystems 13: 507-549. 
MSZ EN, 2014: Water quality. Guidance for the routine sampling and preparation of benthic diatoms from rivers and lakes. MSZ EN 13946:2014. Hungarian Standards Institution, Budapest, p. 18.

Murray, J., Pullar, L. \& Chumley, J., 1910: Bathymetrical survey of the Scottish fresh-water lochs (Vol. 2). Challenger office, Edinburgh, UK.

Revenga, C., Brunner, J., Henniger, N., Kassem, K. \& Payne, R., 2000: Pilot analysis of global ecosystems. Washington, DC: World Resources Institute.

Rimet, F., Cauchie, H.M., Hoffmann, L. and Ector, L., 2005: Response of diatom indices to simulated water quality improvements in a river. Journal of Applied Phycology, 17: $119-128$.

Rott, E., Hofmann, G., Pall, K., Pfister, P. \& Pipp, E., 1997: Indikationslisten für Aufwuchsalgen. Teil 1: Saprobielle IndikationBundesministerium für Land- und Forstwirtschaft, Wien.

Rott, E., Pfister, P., Van Dam, H., Pipp, E., Pall, K., Binder, N. \& Ortler, K., 1999: Indikationslisten für Aufwuchsalgen. Teil 2: Trophieindikation sowie geochemische Präferenz, taxonomische und toxikologische Anmerkungen.Bundesministerium für Land-und Forstwirtschaft, Wien.

Shannon, C. E., 1948: A mathematical theory of communication. Bell System Technical Journal 27:623-56.

Silva, J.G.D., Torgan, L.C. \& Cardoso, L.D.S., 2010: Salt Marsh Diatoms (Bacillariophyceae) in South Brazil. Acta Botanica Brasilica 24: 935-947.

Souffreau, C., Vanormelingen, P., Verleyen, E., Sabbe, K. \& Vyverman, W., 2010: Tolerance of benthic diatoms from temperate aquatic and terrestrial habitats to experimental desiccation and temperature stress. Phycologia 49: 309-324.

Sommer, U., 1984: The paradox of the plankton: fluctuations of phosphorus availability maintain diversity of phytoplankton in flow-through cultures. Limnology and Oceanography 29: 633-636.

Stenger-Kovács, C., Buczkó, K., Hajnal, E. and Padisák, J., 2007: Epiphytic, littoral diatoms as bioindicators of shallow lake trophic status: Trophic Diatom Index for Lakes (TDIL) developed in Hungary. Hydrobiologia, 589: 141-154.

Stenger-Kovács, Cs., Lengyel, E., Buczkó, K., Tóth, M.F. \& Crossetti, O.L., 2014: Vanishing world: alkaline, saline lakes in Central Europe and their diatom assemblages. Inland Waters 4: 383-396. 
Stenger-Kovács, C., Hajnal, É., Lengyel, E., Buczkó, K. and Padisák, J., 2016: A test of traditional diversity measures and taxonomic distinctness indices on benthic diatoms of soda pans in the Carpathian basin. Ecological Indicators, 64: 1-8.

Szilágyi, F., Ács, É., Borics, G., Halasi-Kovács, B., Juhász, P., Kiss, B., Kovács, T., Müller, Z., Lakatos, G., Padisák, J., Pomogyi, P., Stenger-Kovács, Cs., Szabó, K.E., Szalma, E. \& Tóthmérész, B., 2008: Application of water framework directive in Hungary: development of biological classification systems. Water Science Technology 58: 2117 2125.

van Dam, H., Stenger-Kovács, Cs., Ács, É., Borics, G., Buczkó, K., Hajnal, É., SoróczkiPintér, É., Várbíró, G., Tóthmérész, B. \& Padisák, J., 2007: Implementation of the European Water Framework Directive: Development of a system for water quality assessment of Hungarian running waters with diatoms. Archiv für Hydrobiologie Suppl. 161: 339-383.

Várbíró, G., Borics, G., Csányi, B., Fehér, G., Grigorszky, I., Kiss, K.T., Tóth, A. \& Ács, É., 2012: Improvement of the ecological water qualification system of rivers based on the first results of the Hungarian phytobenthos surveillance monitoring. Hydrobiologia 695: $125-135$.

Zenker, A. \& Baier, B., 2009: Relevance of abiotic criteria used in German lake typology for macroinvertebrate fauna. Hydrobiologia 636: 379-392. 


\section{Legends for figures and tables}

Fig. 1 Scheme of the applied biological validation options. The upper arrow indicates how the 17 hydromorphological lake types were established using a top-down approach.

Fig. 2 Nonmetric multidimensional scaling (NMDS) ordination of the hydromorphological lake types (Ordination is based in the Bray-Curtis distances among the types).

Fig. 3 Nonmetric multidimensional scaling (NMDS) ordination of the sites belonging to the groups of moderate salinity calcareous lakes.

Fig. 4 Nonmetric multidimensional scaling (NMDS) ordination of the sites belonging to the groups of high salinity sodium and magnesium dominated lakes.

Fig. 5 Distribution of the Shannon diversity values in the five proposed biologically validated types.

Fig. 6 Distribution of the trophic metric scores in the five proposed biologically validated types.

Table 1 Hydromorphological lake types proposed for Hungary and the applied type descriptor variables.

Table 2 Assignment of biological lake types to hydromorphological types.

Table 3 SIMPER analysis results showing taxa contributing to $25 \%$ of the total similarity within the groups of moderate and high salinity lakes.

Table 4 SIMPER analysis results showing taxa contributing to $25 \%$ of the total similarity within the groups of Balaton and other calcareous lakes.

Table 5 SIMPER analysis results showing taxa contributing to $25 \%$ of the total similarity within the three groups of high salinity lakes.

Table 6 Physical and chemical characteristics of proposed lake types. 


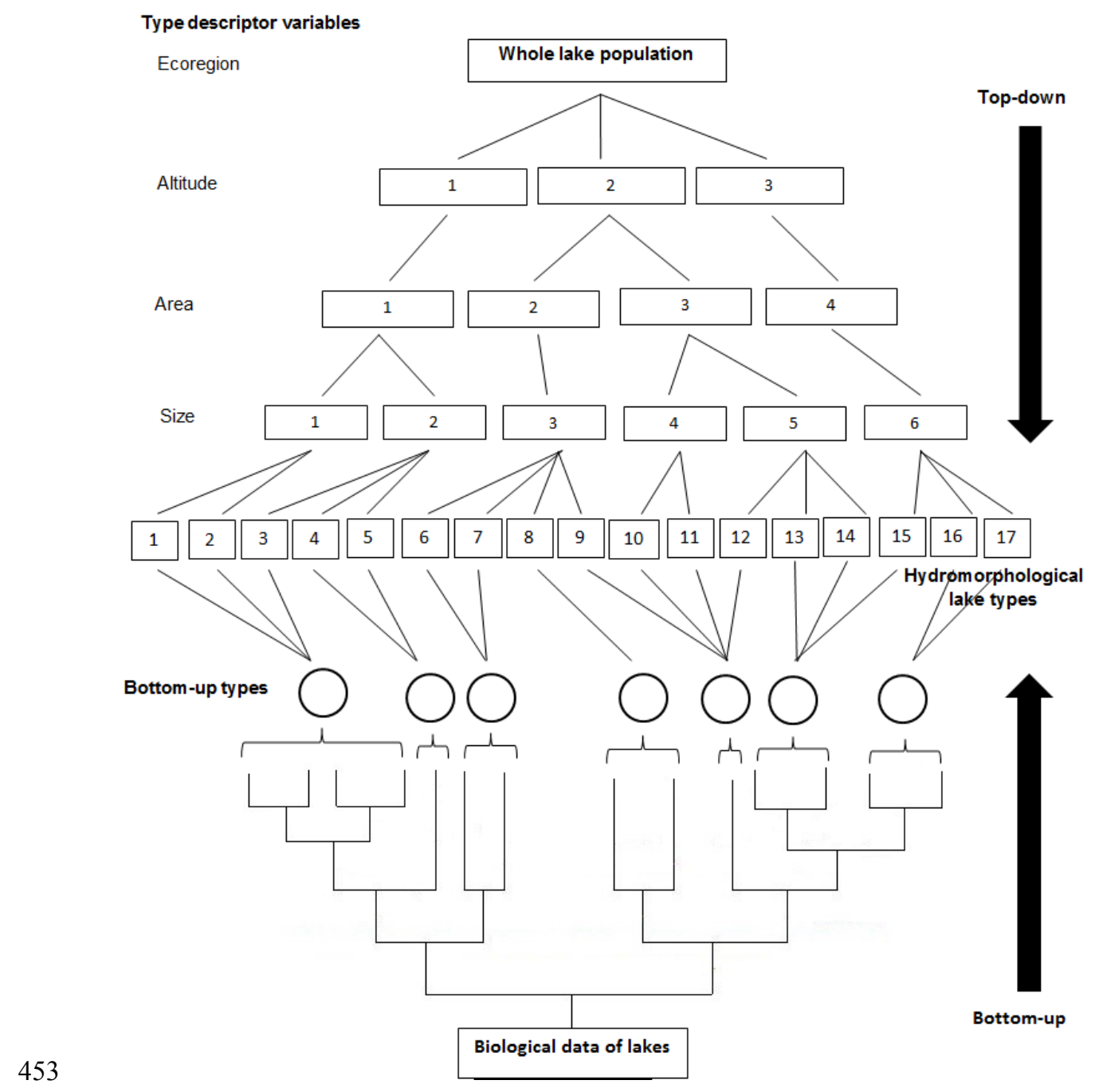

Fig.1.

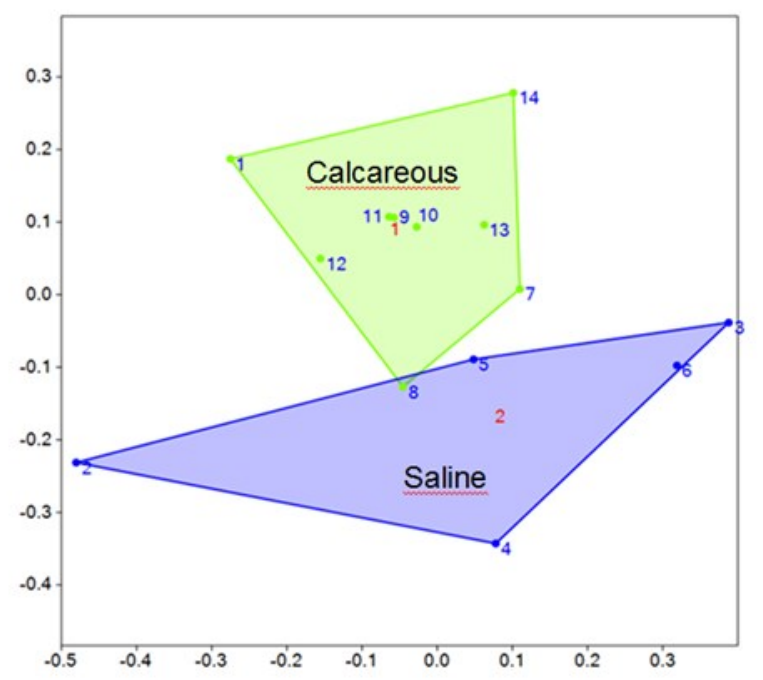

Fig.2. 


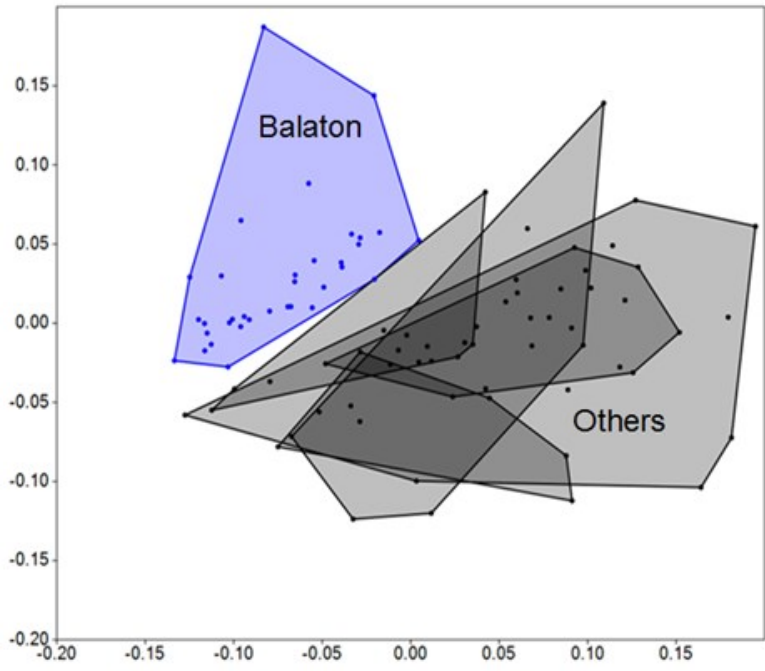

$458 \quad$ Fig.3.

459

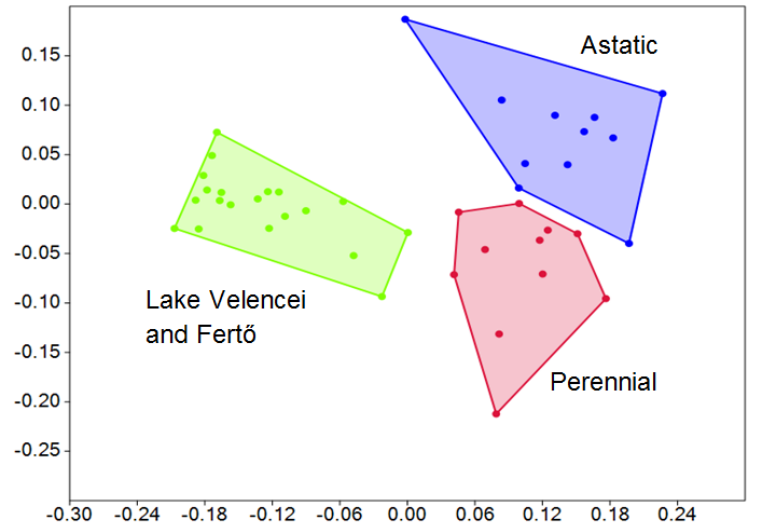

461

Fig.4.

462

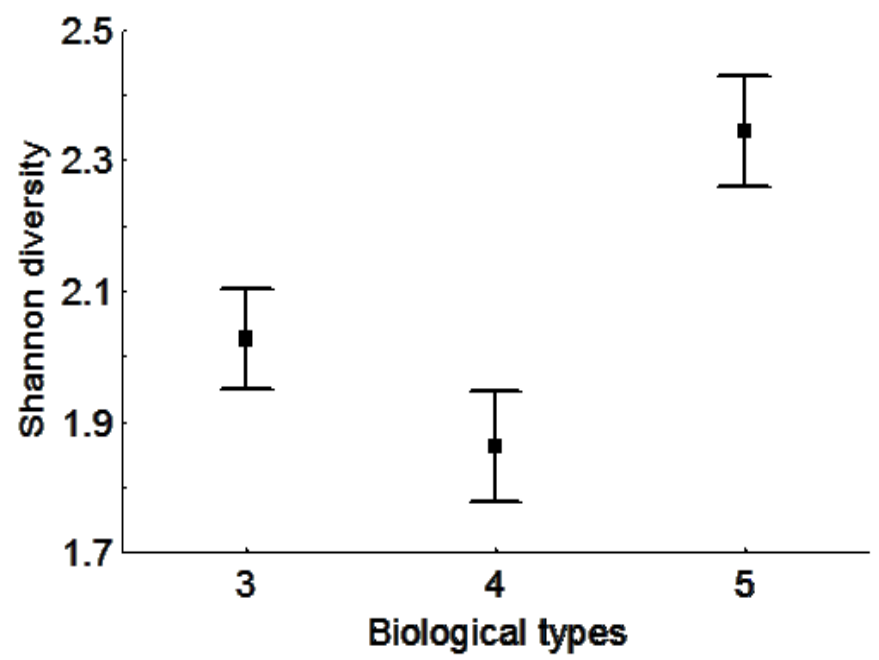

Fig.5. 

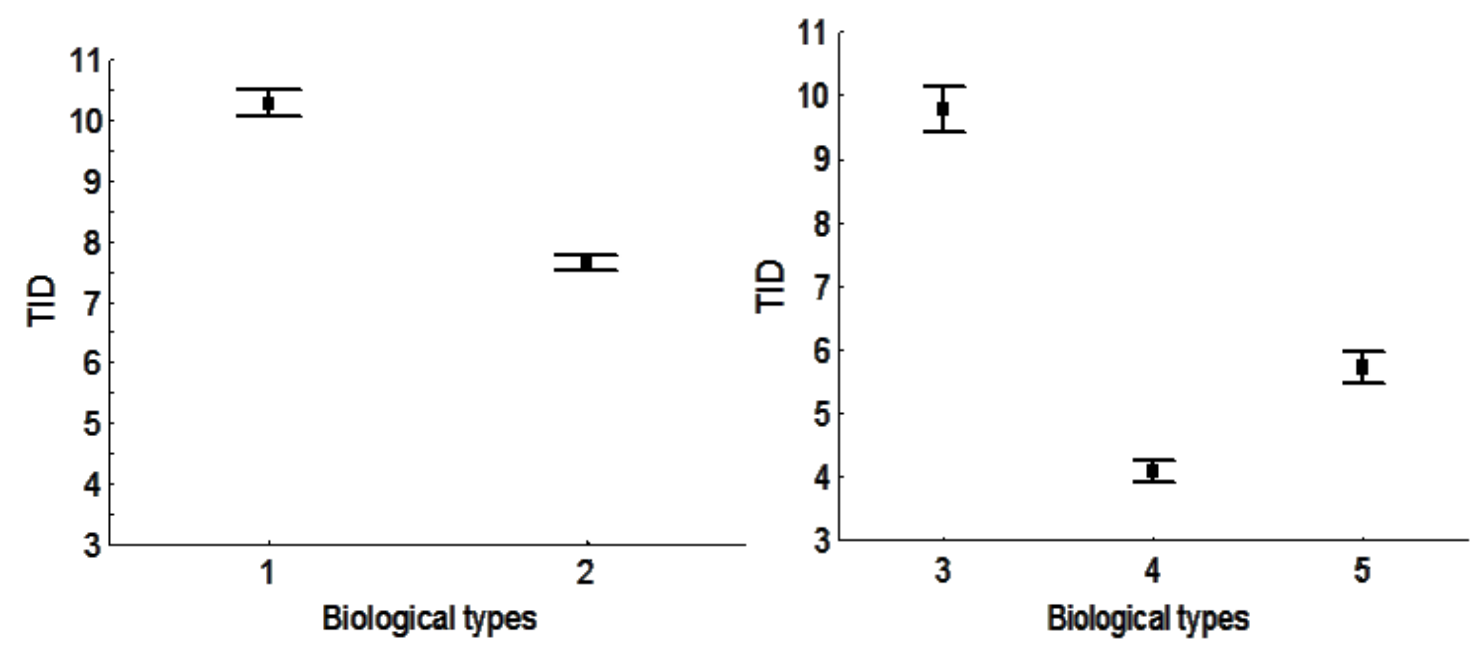

Fig.6.

\begin{tabular}{ccccccc}
\hline Type & Altitude (m) & $\begin{array}{c}\text { Hydrochemical } \\
\text { character }\end{array}$ & Size $\left(\mathrm{km}^{2}\right)$ & $\begin{array}{c}\text { Average } \\
\text { depth }(\mathbf{m})\end{array}$ & $\begin{array}{c}\text { Water } \\
\text { regime }\end{array}$ & $\begin{array}{c}\text { Biological } \\
\text { types }\end{array}$ \\
\hline $\mathbf{1}$ & $<200 \mathrm{~m}$ (lowland) & moderate salinity & $>10\left(\mathrm{~km}^{2}\right)$ & $>3-6 \mathrm{~m}$ & perennial & 1 \\
$\mathbf{2}$ & $<200 \mathrm{~m}$ (lowland) & high salinity & $>10\left(\mathrm{~km}^{2}\right)$ & $<3 \mathrm{~m}$ & perennial & 3 \\
$\mathbf{3}$ & $<200 \mathrm{~m}$ (lowland) & high salinity & $1-10\left(\mathrm{~km}^{2}\right)$ & $<1 \mathrm{~m}$ & astatic & 5 \\
$\mathbf{4}$ & $<200 \mathrm{~m}$ (lowland) & high salinity & $1-10\left(\mathrm{~km}^{2}\right)$ & $<3 \mathrm{~m}$ & perennial & 4 \\
$\mathbf{5}$ & $<200 \mathrm{~m}$ (lowland) & high salinity & $<1\left(\mathrm{~km}^{2}\right)$ & $<3 \mathrm{~m}$ & perennial & 4 \\
$\mathbf{6}$ & $<200 \mathrm{~m}$ (lowland) & high salinity & $<1\left(\mathrm{~km}^{2}\right)$ & $<1 \mathrm{~m}$ & astatic & 5 \\
$\mathbf{7}$ & $<200 \mathrm{~m}$ (lowland) & moderate salinity & $1-10\left(\mathrm{~km}^{2}\right)$ & $<3 \mathrm{~m}$ & perennial & 2 \\
$\mathbf{8}$ & $<200 \mathrm{~m}$ (lowland) & moderate salinity & $<1\left(\mathrm{~km}^{2}\right)$ & $<3 \mathrm{~m}$ & perennial & 2 \\
$\mathbf{9}$ & $<200 \mathrm{~m}$ (lowland) & moderate salinity & $1-10\left(\mathrm{~km}^{2}\right)$ & $<3 \mathrm{~m}$ & perennial & 2 \\
$\mathbf{1 0}$ & $<200 \mathrm{~m}$ (lowland) & moderate salinity & $1-10\left(\mathrm{~km}^{2}\right)$ & $3-6 \mathrm{~m}$ & perennial & 2 \\
$\mathbf{1 1}$ & $<200 \mathrm{~m}$ (lowland) & moderate salinity & $<1\left(\mathrm{~km}^{2}\right)$ & $<3 \mathrm{~m}$ & perennial & 2 \\
$\mathbf{1 2}$ & $<200 \mathrm{~m}$ (lowland) & moderate salinity & $<1\left(\mathrm{~km}^{2}\right)$ & $<3 \mathrm{~m}$ & perennial & 2 \\
$\mathbf{1 3}$ & $<200 \mathrm{~m}$ (lowland) & moderate salinity & $>10\left(\mathrm{~km}^{2}\right)$ & $<3 \mathrm{~m}$ & perennial & 2 \\
$\mathbf{1 4}$ & $<200 \mathrm{~m}$ (lowland) & moderate salinity & $>10\left(\mathrm{~km}^{2}\right)$ & $<3 \mathrm{~m}$ & perennial & 2 \\
$\mathbf{1 5}$ & $>200 \mathrm{~m}$ (hill country) & moderate salinity & $>10\left(\mathrm{~km}^{2}\right)$ & $<3 \mathrm{~m}$ & perennial & 2 \\
$\mathbf{1 6}$ & $>200 \mathrm{~m}$ (hill country) & moderate salinity & $>10\left(\mathrm{~km}^{2}\right)$ & $<1 \mathrm{~m}$ & astatic & 2 \\
$\mathbf{1 7}$ & $<200 \mathrm{~m}$ (lowland) & moderate salinity $<1 ; 1-10\left(\mathrm{~km}^{2}\right)$ & $<3 \mathrm{~m}$ & astatic & 2 \\
\hline
\end{tabular}




\begin{tabular}{lll}
\hline $\begin{array}{l}\text { Codes of the } \\
\text { proposed biological } \\
\text { lake types }\end{array}$ & $\begin{array}{l}\text { Names of the proposed Codes of the } \\
\text { biological lake types }\end{array}$ & $\begin{array}{l}\text { hydromorphological lake } \\
\text { types }\end{array}$ \\
\hline 1 & Balaton & 1 \\
2 & Others & $7,8,9,10,11,12,13,14,15,16,17$ \\
3 & Lake Velencei and Fertő & 2 \\
4 & Perennial & 3,6 \\
5 & Astatic & 4,5 \\
\hline
\end{tabular}

Table 3

\begin{tabular}{|c|c|c|c|c|c|c|}
\hline Taxon & DENOM & Av. dissim & $\begin{array}{c}\text { Contribution } \\
(\%)\end{array}$ & $\begin{array}{c}\text { Cumulative } \\
(\%)\end{array}$ & $\begin{array}{l}\text { Moderate } \\
\text { salinity }\end{array}$ & $\begin{array}{l}\text { High } \\
\text { salinity }\end{array}$ \\
\hline ADMI & Achnanthidium minutissimum (Kützing) Czarnecki 1994 & 1.786 & 2.532 & 2.532 & 12.1 & 9.87 \\
\hline NIS1 & Nitzschia sp. Hassall 1845 & 1.726 & 2.446 & 4.978 & 6.32 & 7.93 \\
\hline EADN & Epithemia adnata (Kützing) Brébisson 1838 & 1.435 & 2.033 & 7.011 & 6.11 & 6.86 \\
\hline HVEN & Halamphora veneta (Kützing) Levkov 2009 & 1.381 & 1.958 & 8.969 & 2.24 & 10.8 \\
\hline RHOS & Rhopalodia species Müller 1895 & 1.24 & 1.757 & 10.73 & 0.561 & 7.87 \\
\hline NCLA & Nitzschia clausii Hantzsch 1860 & 1.182 & 1.675 & 12.4 & 0.284 & 8.19 \\
\hline $\mathrm{NACl}$ & Nitzschia acicularis (Kützing) W.Smith 1853 & 1.128 & 1.598 & 14 & 2.16 & 6.66 \\
\hline RBRE & Rhopalodia brebissonii Krammer in Lange-Bertalot \& Krammer 1987 & 1.084 & 1.537 & 15.54 & 0.0606 & 7.89 \\
\hline NHAN & Nitzschia hantzschiana Rabenhorst 1860 & 0.8474 & 1.201 & 16.74 & 1.93 & 4.96 \\
\hline NLBT & Nitzschia liebetruthii var.liebetruthii Rabenhorst 1864 & 0.8303 & 1.177 & 17.91 & 1.45 & 6.98 \\
\hline CPLI & Cocconeis placentula Ehrenberg 1838 & 0.7983 & 1.131 & 19.05 & 3.48 & 5.33 \\
\hline ETUR & Epithemia turgida (Ehrenberg) Kützing 1844 & 0.7315 & 1.037 & 20.08 & 1.22 & 4.76 \\
\hline RGIB & Rhopalodia gibba var. gibba (Ehrenberg) Otto Müller 1895 & 0.7259 & 1.029 & 21.11 & 1.65 & 5.77 \\
\hline COCE & Cyclotella ocellata Pantocsek 1901 & 0.6806 & 0.9646 & 22.08 & 5.07 & 0.0436 \\
\hline SCON & Staurosira construens Ehrenberg 1843 & 0.6416 & 0.9094 & 22.99 & 3.36 & 3.73 \\
\hline AMIN & Achnanthes minutissima Kützing 1833 & 0.6384 & 0.9048 & 23.89 & 4.72 & 0 \\
\hline CPLA & Cocconeis placentula var. placentula Ehrenberg 1838 & 0.6314 & 0.8949 & 24.79 & 5.2 & 2.38 \\
\hline NIPU & Nitzschia pusilla Grunow 1862 & 0.6239 & 0.8842 & 25.67 & 0.467 & 4.48 \\
\hline APED & Amphora pediculus (Kützing) Grunow ex A.Schmidt 1875 & 0.6048 & 0.8572 & 26.53 & 5.94 & 2.4 \\
\hline GAFF & Gomphonema affine Kützing 1844 & 0.6013 & 0.8523 & 27.38 & 2.6 & 3.66 \\
\hline NDIS & Nitzschia dissipata var.dissipata (Hantzsch) Grunow in Van Heurck 1881 & 0.5676 & 0.8045 & 28.18 & 4.07 & 0.647 \\
\hline CYDE & Cyclotella delicatula Hustedt 1952 & 0.5664 & 0.8027 & 28.99 & 3.97 & 0 \\
\hline NPAL & Nitzschia palea (Kützing) W.Smith 1856 & 0.5085 & 0.7207 & 29.71 & 3.27 & 5.02 \\
\hline EBLU & Eunotia bilunaris (Ehrenberg) Schaarschmidt in Kanitz 1880 & 0.4995 & 0.708 & 30.41 & 2.28 & 3.17 \\
\hline LGOE & Luticola goeppertiana (Bleisch ex Rabenhorst) D.G.Mann in Round, & 0.4962 & 0.7033 & 31.12 & 3.73 & 0.161 \\
\hline SHAN & Stephanodiscus hantzschii Grunow in Cleve \& Grunow 1880 & 0.4768 & 0.6757 & 31.79 & 3.3 & 0.363 \\
\hline ESOR & Epithemia sorex Kützing 1844 & 0.4741 & 0.672 & 32.47 & 4.01 & 2.78 \\
\hline NISO & Nitzschia solita Hustedt 1953 & 0.4674 & 0.6625 & 33.13 & 0.234 & 3.4 \\
\hline AINA & Amphora inariensis Krammer 1980 & 0.4579 & 0.649 & 33.78 & 3.44 & 0.735 \\
\hline NRCS & Navicula recens (Lange-Bertalot) Lange-Bertalot in Krammer \& Lange-Bertalot & 0.4503 & 0.6382 & 34.42 & 0.593 & 3.21 \\
\hline NIPM & Nitzschia perminuta (Grunow) M.Peragallo 1903 & 0.4379 & 0.6207 & 35.04 & 1.19 & 3.85 \\
\hline GINS & Gomphonema insigne W.Gregory 1856 & 0.4373 & 0.6197 & 35.66 & 3.31 & 0.82 \\
\hline ADEU & Achnanthidium eutrophilum (Lange-Bertalot) Lange-Bertalot 1999 & 0.4327 & 0.6133 & 36.27 & 1.35 & 2.67 \\
\hline NVEN & Navicula veneta Kützing 1844 & 0.4302 & 0.6097 & 36.88 & 1.16 & 3.87 \\
\hline MAAT & Mayamaea atomus (Kützing) Lange-Bertalot 1997 & 0.4149 & 0.5881 & 37.47 & 1.4 & 2.49 \\
\hline NAMP & Nitzschia amphibia f.amphibia Grunow 1862 & 0.4104 & 0.5816 & 38.05 & 2.47 & 4.7 \\
\hline
\end{tabular}




\begin{tabular}{|c|c|c|c|c|c|c|c|}
\hline & Taxon & DENOM & Av. dissim & $\begin{array}{c}\text { Contribution } \\
(\%)\end{array}$ & $\begin{array}{c}\text { Cumulative } \\
(\%)\end{array}$ & Balaton & Others \\
\hline 1 & ADMI & Achnanthidium minutissimum (Kützing) Czarnecki 1994 & 8.694 & 10.68 & 10.68 & 33.4 & 13.8 \\
\hline 2 & CEXI & Cymbella exigua Krammer 2002 & 2.367 & 2.907 & 13.58 & 7.1 & 0 \\
\hline 3 & APED & Amphora pediculus (Kützing) Grunow ex A.Schmidt 1875 & 2.068 & 2.54 & 16.12 & 2.13 & 7.12 \\
\hline 4 & NDIS & Nitzschia dissipata (Kützing) Rabenhorst 1860 & 1.585 & 1.946 & 18.07 & 5.07 & 1.71 \\
\hline 5 & GPUM & Gomphonema pumilum (Grunow) E.Reichardt \& Lange-Bertalot 1991 & 1.364 & 1.675 & 19.74 & 4.22 & 0.481 \\
\hline 6 & COCE & Cyclotella ocellata Pantocsek 1901 & 1.326 & 1.628 & 21.37 & 1.41 & 3.22 \\
\hline 7 & ESOR & Epithemia sorex Kützing 1844 & 1.238 & 1.52 & 22.89 & 1.36 & 3.17 \\
\hline 8 & FHUN & Fragilaria hungarica Pantocsek 1901 & 1.223 & 1.502 & 24.39 & 4.05 & 0 \\
\hline 9 & CPLI & Cocconeis placentula Ehrenberg 1838 & & 1.399 & 25.79 & 1.63 & 3.77 \\
\hline 10 & ECPM & Encyonopsis minuta Krammer \& E.Reichardt in Krammer 1997 & 1.106 & 1.359 & 27.15 & 2.09 & 2.1 \\
\hline 11 & NCTE & Navicula cryptotenella Lange-Bertalot in Krammer \& Lange-Bertalot 1985 & 1.046 & 1.285 & 28.44 & 3.11 & 3.75 \\
\hline 12 & ENCM & Encyonopsis microcephala (Grunow) Krammer 1997 & 0.9935 & 1.22 & 29.66 & 2.98 & 0 \\
\hline 13 & EADN & Epithemia adnata (Kützing) Brébisson 1838 & 0.9336 & 1.146 & 30.8 & 0.208 & 3.07 \\
\hline 14 & SGRI & Staurosira grigorszkyi Ács, Morales \& Ector in Ács et al. 2009 & 0.8726 & 1.072 & 31.87 & 2.87 & 0 \\
\hline 15 & HVEN & Halamphora veneta (Kützing) Levkov 2009 & 0.8714 & 1.07 & 32.94 & 0.0442 & 2.61 \\
\hline 16 & DMON & Diatoma moniliformis (Kützing) D.M.Williams 2012 & 0.8519 & 1.046 & 33.99 & 2.71 & 0.305 \\
\hline 17 & SBRV & Staurosira brevistriata (Grunow) Grunow 1884 & 0.8301 & 1.019 & 35.01 & 1.48 & 1.35 \\
\hline 18 & GOMS & Gomphonema species Ehrenberg 1832 & 0.8287 & 1.018 & 36.03 & 2.69 & 0.332 \\
\hline 19 & GOST & Gomphonema olivaceum var.staurophorum Pantocsek 1889 & 0.7915 & 0.9719 & 37 & 2.42 & 0 \\
\hline 20 & UUAC & Ulnaria ulna (Nitzsch) Compère in Jahn et al. 2001 & 0.7913 & 0.9717 & 37.97 & 0.978 & 1.95 \\
\hline
\end{tabular}

482 Table 5

\begin{tabular}{|c|c|c|c|c|c|c|c|c|}
\hline & Taxon & DENOM & Av. dissim & $\begin{array}{c}\text { Contribution } \\
(\%)\end{array}$ & $\begin{array}{c}\text { Cumulative } \\
(\%)\end{array}$ & $\begin{array}{l}\text { Velencei } \\
\text {-Fertő }\end{array}$ & $\begin{array}{c}\text { Small } \\
\text { astatic }\end{array}$ & $\begin{array}{l}\text { Small high } \\
\text { salinity } \\
\text { perennial }\end{array}$ \\
\hline 1 & ADMI & Achnanthidium minutissimum (Kützing) Czarnecki 1994 & 7.935 & 8.91 & 8.91 & 176 & 6.46 & 15.3 \\
\hline 2 & HVEN & Halamphora veneta (Kützing) Levkov 2009 & 5.095 & 5.72 & 14.63 & 0.945 & 130 & 50.5 \\
\hline 3 & NCLA & Nitzschia clausii Hantzsch 1860 & 4.308 & 4.837 & 19.47 & 0 & 139 & 0.182 \\
\hline 4 & GPAR & Gomphonema parvulum (Kützing) Kützing 1849 & 3.573 & 4.011 & 23.48 & 1.46 & 89.4 & 35.3 \\
\hline 5 & CPLI & Cocconeis placentula Ehrenberg 1838 & 3.107 & 3.488 & 26.97 & 53.8 & 27 & 4.68 \\
\hline 6 & NPAL & Nitzschia palea (Kützing) W.Smith 1856 & 2.412 & 2.709 & 29.68 & 3.5 & 43.5 & 53.3 \\
\hline 7 & NLBT & Nitzschia liebetruthii var.liebetruthii Rabenhorst 1864 & 2.402 & 2.697 & 32.37 & 3.58 & 58.5 & 24.8 \\
\hline 8 & NIPU & Nitzschia pusilla Grunow 1862 & 2.142 & 2.405 & 34.78 & 0.2 & 72.8 & 2.05 \\
\hline 9 & RGIB & Rhopalodia gibba (Ehrenberg) Otto Müller 1895 & 2.081 & 2.337 & 37.11 & 12.4 & 2.85 & 56.4 \\
\hline 10 & EADN & Epithemia adnata (Kützing) Brébisson 1838 & 1.693 & 1.901 & 39.01 & 3.24 & 2.24 & 47.3 \\
\hline 11 & CMEN & Cyclotella meneghiniana Kützing 1844 & 1.625 & 1.824 & 40.84 & 1.17 & 20.5 & 36 \\
\hline 12 & ACHD & Achnanthidium F.T. Kützing & 1.549 & 1.739 & 42.58 & 42.3 & 0 & 0 \\
\hline 13 & NIGR & Nitzschia gracilis Hantzsch 1860 & 1.545 & 1.735 & 44.31 & 1.88 & 1.33 & 52.1 \\
\hline 14 & NINC & Nitzschia inconspicua Grunow 1862 & 1.453 & 1.631 & 45.94 & 1.49 & 22.3 & 32.5 \\
\hline 15 & NAMP & Nitzschia amphibia f.amphibia Grunow 1862 & 1.367 & 1.535 & 47.48 & 6.71 & 14.7 & 31.7 \\
\hline 16 & NIFR & Nitzschia frustulum var.frustulum (Kützing) Grunow in Cleve \& Grunow 1880 & 1.329 & 1.492 & 48.97 & 7.81 & 15.2 & 30.8 \\
\hline 17 & ESBM & Eolimna subminuscula (Manguin) Gerd Moser, Lange-Bertalot \& Metzeltin 1998 & 1.325 & 1.487 & 50.46 & 0.275 & 5.94 & 33.3 \\
\hline 18 & ESOR & Epithemia sorex Kützing 1844 & 1.118 & 1.255 & 51.71 & 10.8 & 1.23 & 28.5 \\
\hline 19 & ADEU & Achnanthidium eutrophilum (Lange-Bertalot) Lange-Bertalot 1999 & 1.087 & 1.22 & 52.93 & 2.05 & 46.4 & 0.727 \\
\hline 20 & NCRY & Navicula cryptocephala Kützing 1844 & 1.087 & 1.22 & 54.15 & 1.32 & 24.7 & 7.67 \\
\hline
\end{tabular}

\begin{tabular}{|c|c|c|c|c|c|c|c|c|c|c|c|c|c|c|c|}
\hline \multirow[t]{2}{*}{ Type } & \multicolumn{3}{|c|}{1} & \multicolumn{3}{|c|}{2} & \multicolumn{3}{|c|}{3} & \multicolumn{3}{|c|}{ 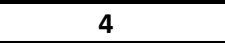 } & \multicolumn{3}{|c|}{5} \\
\hline & $n$ & mean & SE & $\mathbf{n}$ & mean & SE & $\mathbf{n}$ & mean & SE & $\mathrm{n}$ & mean & SE & $n$ & mean & SE \\
\hline Conductivity $\left(\mu \mathrm{S}^{*} \mathrm{~cm}^{-1}\right)$ & 21 & 718 & 6 & 157 & 647 & 25 & 27 & 2547 & 100 & 19 & 1930 & 142 & 38 & 5199 & 480 \\
\hline pH & 24 & 8.5 & 0 & 139 & 8.02 & 0 & 6 & 8.56 & 0 & 19 & 8.63 & 0 & 37 & 9.13 & 0 \\
\hline Total phosphorus $\left(\mu \mathrm{g}^{\star} \mathrm{I}^{-1}\right)$ & 24 & 48 & 3 & 152 & 175 & 18 & 30 & 71 & 4 & 19 & 695 & 243 & 38 & 4680 & 623 \\
\hline Total nitrogen $\left(\mu \mathrm{g}^{*} \mathrm{I}^{-1}\right)$ & 24 & 906 & 18 & 151 & 1583 & 96 & 30 & 2091 & 112 & 18 & 4719 & 992 & 38 & 10652 & 2058 \\
\hline Magnesium $\left(\mathrm{mg}^{*} \mathrm{I}^{-1}\right)$ & 24 & 61 & 1 & 35 & 37 & 4 & 30 & 214 & 11 & 18 & 64 & 7 & 30 & 23 & 4 \\
\hline Natrium $\left(\mathrm{mg}^{*} \mathrm{I}^{-1}\right)$ & 24 & 41 & 1 & 47 & 49 & 6 & 30 & 335 & 16 & 18 & 369 & 43 & 31 & 1222 & 127 \\
\hline Calcium $\left(\mathrm{mg}^{*} \mathrm{I}^{-1}\right)$ & 24 & 40 & 1 & 47 & 52 & 2 & 30 & 30 & 2 & 18 & 32 & 3 & 30 & 22 & 2 \\
\hline Potassium $\left(\mathrm{mg}^{*} \mathrm{l}^{-1}\right)$ & 24 & 8 & 1 & 47 & 7 & 1 & 30 & 48 & 2 & 18 & 20 & 3 & 31 & 17 & 3 \\
\hline
\end{tabular}

